\title{
Soil Seed Bank of Plant Species as a Function of Long-Term SoIl Management and SAMPled DePTH ${ }^{1}$
}

\author{
Banco de Sementes de Espécies Vegetais em Função de Distintos Manejos do Solo por Longo \\ Período e Profundidade Amostrada
}

CONCENÇO, G. ${ }^{2}$, SALTON, J.C. ${ }^{3}$, BREVILIERI, R.C. ${ }^{4}$, MENDES, P.B. ${ }^{4}$ and SECRETTI, M.L. ${ }^{4}$

\begin{abstract}
This study aimed at assessing the level of weed infestation indifferent areas that were submitted to different soil management for 16 years. Four management systems were studied: (1) agriculture only under conventional tillage system; (2) agriculture only under no-till system; (3) crop-livestock integrationcrop-livestock integration; (4) livestock only. These areas were sampled at three soil depths (0-5, 5-10 and 10-15 cm), and soil was stored in plastic pots and taken to a greenhouse, where soil moisture and weight were standardized. Soil was kept near 70\% moisture field capacity, being revolved every 20 days when all seedling emerged from soil were counted, identified and collected for dry mass assessment. The soil coverage by weeds, number of weed seedlings and dry mass of the weedy community were assessed. A phytoecological analysis was conducted. Weed composition is differentdifferent among management systems after 16 years. Areas with livestock showed much smaller number of weed species in comparison to systems where only grain crops are grown. The presence of livestock affects the potential of germination of soil seed bank. Agriculture systems are similar in terms of weed composition along soil profile, while systems involving livestock show little relation in what regards such sampled depths. Conservationist models of land exploration contribute to reduce severity of weed species occurrence in the long term.
\end{abstract}

Keywords: weeds, cropping systems, crop-livestock integration.

\begin{abstract}
RESUMO - Objetivou-se avaliar o nivel de infestação por plantas daninhas em áreas submetidas a manejos distintos por 16 anos: (1) agricultura em sistema convencional de preparo; (2) agricultura em sistema plantio direto; (3) integração lavoura/ pecuária; (4) somente pecuária. Amostras de solos destas áreas foram coletadas em três profundidades (0-5, 5-10 and $10-15 \mathrm{~cm})$, depositadas em potes plásticos e levadas a casa de vegetação. O solo era revolvido a cada 20 dias, quando as plantas daninhas presentes eram identificadas e coletadas. Foram avaliados cobertura por plantas daninhas; densidade de plantas daninhas e massa seca da comunidade infestante. Foi também conduzida análise fitoecológica em função dos distintos manejos e profundidades. Áreas onde pastagens estiveram presentes tiveram menor infestação por plantas daninhas que áreas onde somente agricultura era utilizada. A composição floristica difere entre sistemas de manejo. Áreas onde a pecuária está presente apresentaram número de plântulas de espécies daninhas muito inferior a sistemas onde somente agricultura está presente. A presença de criação de gado afeta o potencial de emergência das espécies presentes no banco de sementes do solo. Sistemas de agricultura sem integração apresentam alta similaridade em termos de composição de espécies ao longo do perfil do solo enquanto sistemas integrados com pecuária apresentam pouca relação entre as profundidades amostradas. Modelos conservacionistas de exploração do solo contribuem com a redução da severidade de ocorrência de espécies daninhas a longo prazo.
\end{abstract}

Palavras-chave: plantas daninhas, sistemas de cultivo, integração lavoura-pecuária.

1 Recebido para publicação em 23.3.2011 e aprovado em 23.5.2011.

2 Agronomist, Ph.D. in Plant Breeding, Weed Science researcher at Embrapa Western Region Agriculture, Dourados-MS, Brazil, <germani@cpao.embrapa.br>; ${ }^{3}$ Agronomist, Ph.D. in Soil Science, researcher at Embrapa Western Agriculture, Dourados-MS, Brazil, <salton@cpao.embrapa.br>; ${ }^{4}$ Agronomist, trainee at Embrapa Western Agriculture, Dourados-MS, Brazil 


\section{INTRODUCTION}

Studies related to weed behavior are essential for agriculture sustainability in tropical soils, once their interference can cause significant yield losses, especially in crops with low competitive ability. One of the mechanisms which ensure survival of a given species under constantly disturbed environments, especially for annual plants, is the ability to produce a high number of seeds. Deuber (1992) discusses about several weeds with high seed production, for instance Amaranthus spp. - 120.000 seeds per plant, Galinsoga parviflora - 30.000 seeds per plant and Portulaca oleracea-53.000 seeds per plant. In an adverse and constantly disturbed environment these species usually tend to occur increasingly more often, covering most of the area and causing more problems for commercial crops. In addition, factors related to herbicide tolerance (Norsworthy et al., 2001) and resistance (Mas et al., 2010) may contribute for the higher occurrence of a given weed species inside a plant community.

Among different soil managements, no-till cropping systems can shift the dynamics of weed species at the soil seed bank and also modify the efficacy of soil-applied herbicides, due to soil coverage and possible herbicide interception by crop residues (Bulher et al., 1996). Moreover, even shifting the number and composition of weeds, some species may be more difficult to control under no-till systems than under conventional tillage systems (Deuber, 1992; Pitelli \& Pitelli, 2008).

To understand not only the level of occurrence, but also the composition of the weed community under each cropping system, is important to achieve successful control. Research data show that management systems with low soil disturbance allow the formation of a bigger and more diverse weed seed bank in soil. Under no-till system, the presence of straw from previous crops is important to reduce the emerging percentage of some weed species, since it increases the occurrence of others (Voll et al., 2005).

Besides cropping systems, recent publications point to a closer integration between crop and livestock production under no-till system, as the basis for sustainability of agribusiness at the Cerrado region of Brazil (Voll et al., 2005). One of the most significant advantages of such integration is the reduction of weed occurrence, by reducing the soil seed bank more efficiently than when using only herbicides for weed control - which usually does not affect dormant seeds in soil. In addition, this integration makes it possible to manage the resistance of some weeds to herbicides, once grazing is almost a nonselective method of weed control (Voll et al., 2005).

This study aimed at assessing the level of weed infestation in different areas that were submitted to different soil management for sixteen years.

\section{MATERIAL AND METHODS}

The trial comprises an area of 28 ha of a clayey Ferralsol (Oxisol) and was installed in 1995 at the Experimental Station owned by Embrapa Western Region Agriculture, in the city of Dourados, in the state of Mato Grosso do Sul, Brazil. Geographical coordinates of the long-term trial are $22^{\circ} 14^{\prime} \mathrm{S}-54^{\circ} 49^{\prime} \mathrm{W}$ with $430 \mathrm{~m}$ altitude. A complete survey about soil class can be found in Amaral et al. (2000).

Before the trial, the area was being used for grain crops under conventional soil tillage since the 70's. This site is in a transitional area between the Cerrado and Atlantic Forest biomes, whose climate is classified by Köpen as Cwa mesothermal humid climate, with hot summers and dry winters (Fietz \& Fisch, 2006).

Different soil and cropping management systems were started in 1995 and since then these areas have been managed as follows:

Conventional: Grain crops grown under conventional soil tillage, with monoculture of soybeans in summer and oats in winter; soil tillage is conducted with disc harrow in a plot of 2 hectares (ha);

No-till: Grain crops grown under no-till in an area of 6 ha, with crop rotation including soybean and corn grown in two hectares each in the summer. During the fall-winter and spring, wheat and oats are planted for grains, and oats and turnip are planted for straw deposition, keeping the following sequence: ... 
/ turnip / corn / oat / soybean / wheat / soybean / ...

CLI: Crop-livestock integration: Rotation of crops (soybean/oats) and livestock (Brachiaria decumbens) conducted under no-till, cycle of every two years. Each subplot covers 4 ha, in a total of 8 ha, and pastures are grazed by Nelore cattle with stocking rate adjusted to maintain a constant supply of forage around $7 \%(7 \mathrm{~kg}$ of dry mass for $100 \mathrm{~kg}$ of livestock per day). Soil fertilization or liming is conducted only in grain crops along the crop rotation.

Livestock: Continuous livestock: area of 4 ha where Brachiaria decumbens is grown under rotational grazing, with the number of animals adjusted to keep constant forage supply around $7 \%$. This forage area was initiated in 1995 and no fertilizer or lime have been applied since then.

Phytoecological characterization of weed species that emerged from soil seed bank was carried out at $0-5,5-10$ and $10-15 \mathrm{~cm}$ depths, in each one of the four previously characterized areas. In order to do so, five samples of $484 \mathrm{~cm}^{2}$ for each studied depth were collected in each area. Then, samples were subjected to soil moisture determination, being corrected to $70 \%$ of field capacity and placed in 2 liter PVC pots. These pots were identified and placed on benches in a greenhouse, in a completely randomized design with five replications. Every 20 days after treatment was initiated, all the seedlings emerged were identified and collected. There was a total of four collections and the last one occurred 80 days after assembly. After each count, the soil from the containers was revolved so that the seed bank could show its potential.

For each species presented, estimations of relative frequency, relative dominance and relative abundance were done. These variables describe the relationship of each species with the others at the same area. The Importance Value Index (IVI), that describes which species are the most important within the studied area, was also determined according to Mueller-Dombois \& Ellenberg models (1974). After this analysis, areas and depths inside the same area were compared by the Sørensen's similarity coefficient (1957) in a way to estimate the current degree of weeds similarities between sampled areas after 16 years of different management.

\section{RESULTS AND DISCUSSION}

The chemical analysis of the soil under different managements is shown in Table 1, with concentrations of major elements at 0-5 and $5-15 \mathrm{~cm}$ depths. In general, it is possible to observe that the shallower depth is more fertile, richer in organic matter, and less acid than the deeper depth, except for the conventional treatments where the soil profile seems to be uniform along sampled depths (Table 1). When Mas et al. (2010) studied the species composition inside agricultural systems of Pampa in Argentina, they observed that the most significant changes in the functional structure of weed communities occurred in fields with medium productivity

Table 1 - Chemical soil analysis at two depths as a function of soil management. Embrapa Western Agriculture, Dourados-MS, Brazil, 2011

\begin{tabular}{|c|c|c|c|c|c|c|c|c|c|c|c|c|c|}
\hline \multirow{2}{*}{ System } & Depth & $\mathrm{pH}$ & $\mathrm{Al}$ & $\mathrm{K}$ & $\mathrm{Ca}$ & $\mathrm{Mg}$ & CEC & \multirow{2}{*}{$\frac{\text { O.M. }}{\left(\mathrm{g} \mathrm{kg}^{-1}\right)}$} & $\mathrm{P}$ & $\mathrm{Fe}$ & $\mathrm{Mn}$ & $\mathrm{Zn}$ & $\mathrm{Cu}$ \\
\hline & $(\mathrm{cm})$ & $\left(\mathrm{H}_{2} \mathrm{O}\right)$ & \multicolumn{5}{|c|}{$\left(\mathrm{cmol}_{\mathrm{c}} \mathrm{dm}^{-3}\right)$} & & \multicolumn{5}{|c|}{$\left(\mathrm{mg} \mathrm{dm}^{-3}\right)$} \\
\hline \multirow{2}{*}{ Conventional } & $0-5$ & 5.84 & 0.18 & 0.53 & 5.52 & 2.18 & 14.2 & 32.3 & 23.1 & 22.8 & 85.3 & 1.7 & 17.5 \\
\hline & $5-15$ & 5.63 & 0.34 & 0.39 & 5.06 & 2.01 & 14.2 & 29.7 & 18.2 & 23.7 & 70.4 & 1.4 & 17.3 \\
\hline \multirow{2}{*}{ No-till } & $0-5$ & 6.50 & 0.07 & 1.16 & 8.23 & 3.35 & 15.9 & 38.9 & 48.5 & 22.2 & 134.2 & 2.9 & 13.6 \\
\hline & $5-15$ & 5.40 & 0.74 & 0.43 & 4.59 & 2.06 & 15.8 & 26.8 & 30.2 & 28.3 & 69.6 & 1.8 & 17.6 \\
\hline \multirow{2}{*}{$\begin{array}{l}\text { Crop-livestock } \\
\text { integration }\end{array}$} & $0-5$ & 6.30 & 0.05 & 1.01 & 7.51 & 3.50 & 16.0 & 45.4 & 16.9 & 27.0 & 125.2 & 3.1 & 13.3 \\
\hline & $5-15$ & 5.46 & 0.64 & 0.32 & 4.21 & 2.16 & 15.2 & 26.4 & 10.0 & 26.9 & 77.8 & 1.4 & 16.5 \\
\hline \multirow{2}{*}{ Livestock } & $0-5$ & 6.45 & 0.05 & 1.18 & 7.33 & 3.61 & 16.0 & 51.7 & 10.9 & 28.5 & 138.1 & 3.0 & 14.5 \\
\hline & $5-15$ & 5.67 & 0.19 & 0.40 & 4.69 & 2.53 & 14.6 & 31.5 & 2.8 & 25.6 & 101.0 & 1.0 & 17.5 \\
\hline
\end{tabular}


soils. The authors state that this was expected, since low and high productivity soils have strong organizing factors - low availability of soil resources and crop competition respectively - that may reduce the influence of crop management on weed structuring.

From now on, sampled soil depths will be referred as follows: $(0-5 \mathrm{~cm})=$ shallower; $(5-10 \mathrm{~cm})=$ intermediary; $(10-15 \mathrm{~cm})=$ deeper. These are the sampled depths at the field - all plots were at similar conditions of distribution and light/water availability at the greenhouse trial.

The percentage of area covered by weeds varied greatly on treatments (Figure 1). For the conventional tillage system, from $20 \%$ to $26 \%$ of the area was covered with weeds after 20 days of soil disturbance. When depths are compared under this tillage system, it is possible to observe that deeper layers $(5-10 \mathrm{~cm}$ and $10-15 \mathrm{~cm}$ ) presented similar infestation severity, while the shallower layer $(0-5 \mathrm{c} \mathrm{m})$ presented higher infestation, according to standard deviations (Figure 1). Interestingly, the soil under no-till system (no tillage at all) presented an overall potential of infestation by weeds superior to that observed at the conventional tillage system. For the deeper layer $(5-15 \mathrm{~cm})$, the area covered by weeds remained from 29 to $33 \%$ while for the shallower depth the area covered by weeds reached around 55\% (Figure 1). This issue will be addressed later, when flora composition at these treatments will be discussed in more detail.

In relation to the treatments with livestock included (sole or in rotation with crops), the area covered by weeds was much smaller than that for treatments with continuous succession of grain crops only (Figure 1). In addition, for the crop/livestock integration the shallower depth presented smaller infestation than the $5-10 \mathrm{~cm}$ depth, showing that the absence of tillage in soil associated to the intermittent grazing allowed elimination of weeds that emerged from the seed bank at the shallower depths, while forcing seeds at the intermediary depth to go into a dormant or quiescent state. At the treatment under continuous pasture, the area covered by weeds was much smaller compared to the other treatments, indicating an exhausted seed

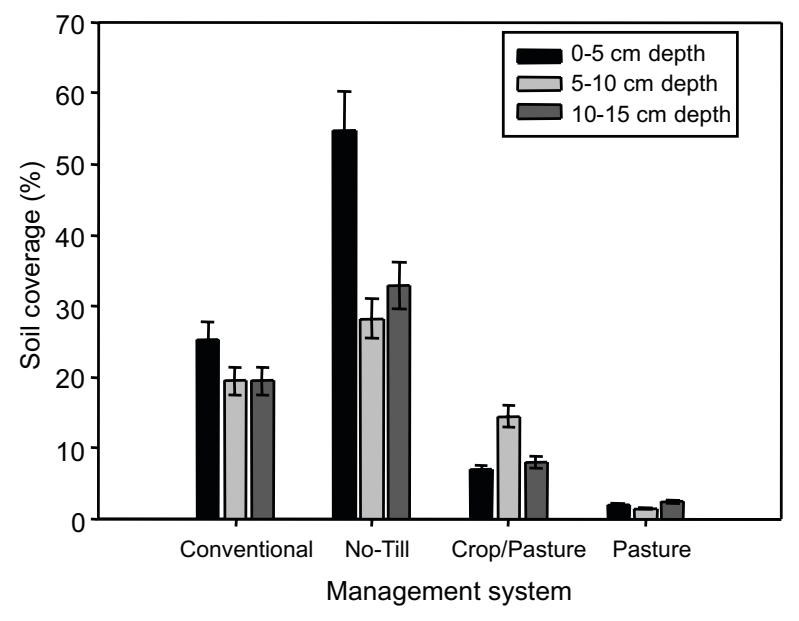

Figure 1 - Soil covered by weed species after 20 days of soil disturbance, average of four disturbances, in soils submitted to different managements and uses for 16 years, sampled at different depths. Embrapa Western Agriculture, DouradosMS, Brazil, 2011

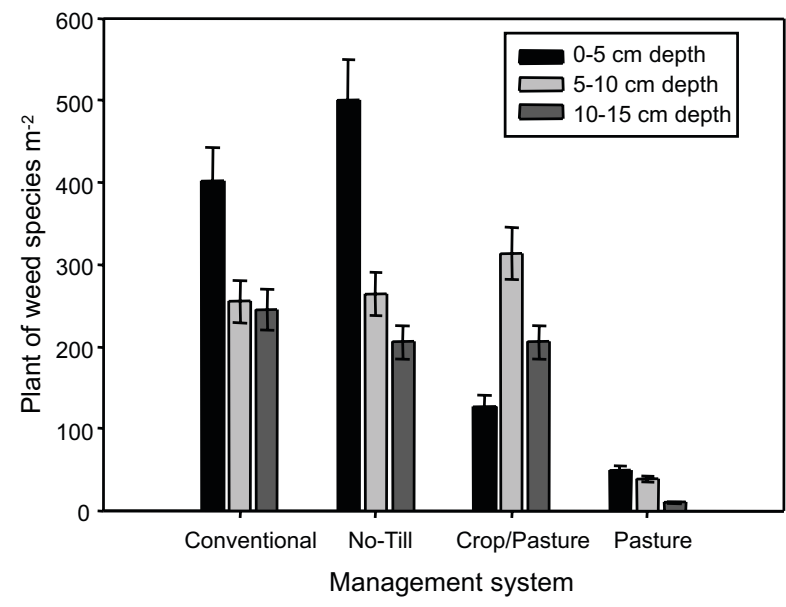

Figure 2 - Total number of seedlings and plants of weed species per square meter after four soil disturbances spaced in 20 days, in soils submitted to different managements and uses for 16 years, sampled at different depths. Embrapa Western Agriculture, Dourados-MS, Brazil, 2011.

bank, where most of the seeds were forced to a dormant or quiescent for such a long time that part of them had lost potential of germination (Morbidoni et al., 2008; Yamashita et al., 2009).

A similar behavior was observed for number of plants per square meter (Figure 2), where treatments with no livestock (conventional tillage and no-till) presented similar number of plants per square meter at the two deeper 
depths, while no-till presented higher infestation than the conventional tillage system at the shallower depth (Figure 2). A remarkable discrepancy was observed in the area covered by weeds (Figure 1) and density of plants (Figure 2) for the crop/livestock integration, compared to the other treatments. In general, while the area covered by weeds was smaller at the integration when compared to the conventional and no-till treatments, the density of plants was similar among the three treatments, indicating that the size of the plants at this treatment was smaller than that observed at the others, probably as a consequence of a delayed emergence. Such delayed emergence is most probably a consequence of the time needed for seeds forced to a quiescent or dormant state to restart their metabolism and allow germination (Severino, 2005). In practical terms, weed infestation at this area would be less severe when a given crop is planted due to the time needed for plants of the weed species to establish themselves, allowing plants to have good advantage in development and causing the crop canopy to shade seedlings of the weed species and block their development (Putnan \& DeFrank, 1983; Pitelli \& Pitelli, 2008). Regarding soil coverage (Figure 1), the area under continuous livestock also presented a smaller number of plants per area (Figure 2).

The dry mass of the weedy community (Figure 3) was generally similar to the area covered by weeds (Figure 1), noting once more a higher infestation at the $0-5 \mathrm{~cm}$ depth at the no-till area. Livestock areas showed smaller dry mass of weeds than areas where only crops are grown (Figure 3 ). The dry mass is a function not only of the number of seedlings at the area, but also of how many days after emergence these seedlings grow, as previously mentioned. Accordingly, it is possible to emphasize that seeds at soils sampled at 5-10 $\mathrm{cm}$ and $10-15 \mathrm{~cm}$ depths, when put under similar favorable conditions, took longer to germinate than seeds at soil from 0 to $5 \mathrm{~cm}$ depth, because the number of seedlings was higher (Figure 2) in comparison to the amount of dry mass they were able to accumulate (Figure 3) after emergence. This is particularly true for the crop/livestock integration area.
There are two mechanisms that can be related to the lower infestation and delayed emergence of seedlings in areas that have livestock., The first mechanism regards allelopathic issues. Aconitic acid is a substance that is commonly exudated by grasses such as Brachiaria species, which is responsible both for direct inhibition of plant growth (Putnan \& DeFrank, 1983; Friebe et al., 1995) and for growth stimulus of endophytic fungus capable of attacking seeds at the soil (Voll et al., 2004). According to Voll et al. (2010), aconotic acid affects the soil seed bank and its germination, which results in smaller competitive ability of the overall weedy community against the crop at the area.

The second mechanism regards the direct presence and action of livestock at the area grazing (Popay \& Field, 1996) and trampling (Marchezan et al., 2003), which could both reduce production of new seeds and vegetative propagules from weed species, and help forcing quiescent seeds to dormancy and later loss of their viability.

At the phytoecological analysis, the following abbreviations are used: $(\mathrm{Rab})=$ relative abundance; $(\mathrm{Rfr})=$ relative frequency; $($ Rdo $)=$ relative dominance $;(\mathrm{IVI})=$ importance value index. Rab, Rfr and Rdo range from $0 \%$ to $100 \%$, while IVI ranges from $0 \%$ to $300 \%$ as it is the sum of the previous three factors. For

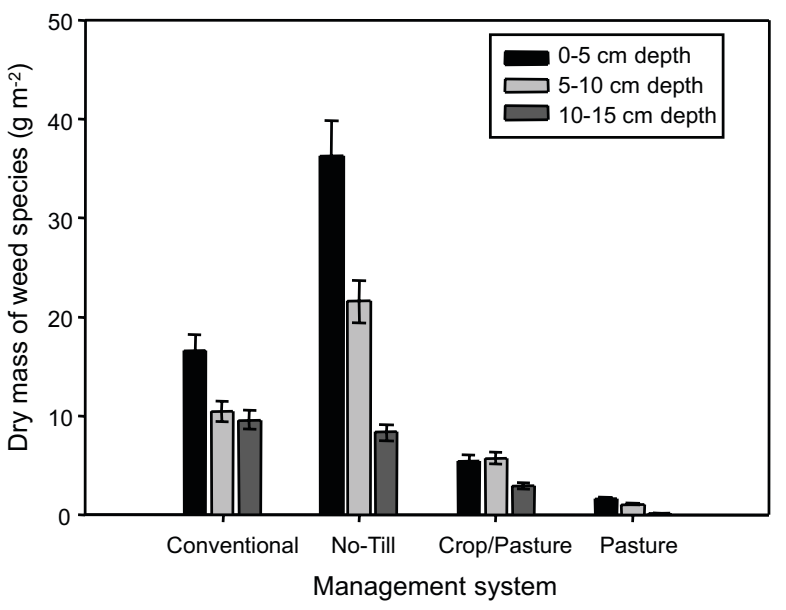

Figure 3 - Total dry mass of weed species $\left(\mathrm{g} \mathrm{m}^{-2}\right)$ after four soil disturbances spaced in 20 days, in soils submitted to different managements and uses for 16 years, sampled at different depths. Embrapa Western Agriculture, Dourados-MS, Brazil, 2011.

Planta Daninha, Viçosa-MG, v. 29, n. 4, p. 725-736, 2011 
each area and depth, the most abundant, frequent, and dominant species are highlighted, as well as the species with higher IVI's (sum of the previous factors) - Tables 2, 3,4 and 5 .

For the conventional tillage, agriculture only area (Table 2), it is possible to observe that Avena sativa (Rab, Rfr, Rdo, IVI), Leonotis nepetifolia (Rfr, IVI) and Raphanus sativus (Rab, Rdo, IVI) were the most significant weed species at the $0-5 \mathrm{~cm}$ depth. Similar results were found for $510 \mathrm{~cm}$ depth, however at the shallower depth, Raphanus sativus was the most significant weed species, while for the intermediary depth $(5-10 \mathrm{~cm})$, Avena sativa was the most significant one (Rab, Rfr, Rdo, IVI). At the deeper depth $(10-15 \mathrm{~cm})$, Commelina benghalensis (Rdo, IVI), Avena sativa (Rab, Rfr, Rdo, IVI) and Leonotis nepetifolia (Rfr, IVI) were the most significant weed species
(Table 2). Around 41\% of the infestation at this management system was formed by seeds of weed species from the shallower depth, 30\% at the intermediary, and $29 \%$ emerged from soil collected at the deeper depth.

The Raphanus sativus (turnip) species is usually used to protect the soil such as in winter cropping. It is a vigorous plant which covers around $70 \%$ of the soil in 60 days after planting, if well established. The dynamic growth of Avena sativa (black oat)tend to control most weeds. A few tall broadleaf weeds can occasionally be a problem in areas where oats are planted, but these can be easily controlled with broadleaf herbicide. Leonotis nepetifolia (klip dagga) is a common, but low competitive weed, which is usually either easily controlled with herbicides or suppressed by other plant species. Commelina benghalensis (tropical spiderwort) is a prostrate weed which is

Table 2 - Analysis of weed species and their significance in soil submitted to conventional tillage system (agriculture only) for 16 years, sampled at different depths. Embrapa Western Agriculture, Dourados-MS, Brazil, 2011

\begin{tabular}{|c|c|c|c|c|c|}
\hline & Conventional system (agriculture only) & Rel. abund* & Relat. freq* & Relat. domin* & IVI* \\
\hline \multirow{6}{*}{$0-5 \mathrm{~cm}$} & Amaranthus retroflexus & 1.95 & 2.56 & 3.75 & 8.26 \\
\hline & Avena sativa & 11.67 & 12.82 & 7.24 & 31.73 \\
\hline & Commelina benghalensis & 3.11 & 2.56 & 4.56 & 10.23 \\
\hline & Ipomoea grandifolia & 0.78 & 2.56 & 0.80 & 4.15 \\
\hline & Leonotis nepetifolia & 8.17 & 12.82 & 6.97 & 27.96 \\
\hline & Raphanus sativus & 13.62 & 5.13 & 21.98 & 40.73 \\
\hline & $0-5 \mathrm{~cm}(\%)$ & 39.30 & 38.46 & 45.31 & 123.07 \\
\hline \multirow{6}{*}{$5-10 \mathrm{~cm}$} & Avena sativa & 14.40 & 12.82 & 11.80 & 39.01 \\
\hline & Commelina benghalensis & 4.28 & 5.13 & 5.36 & 14.77 \\
\hline & Leonotis nepetifolia & 5.84 & 7.69 & 1.34 & 14.87 \\
\hline & Raphanus sativus & 3.89 & 2.56 & 9.65 & 16.11 \\
\hline & Sida rhombifolia & 1.95 & 2.56 & 0.27 & 4.78 \\
\hline & $5-10 \mathrm{~cm}(\%)$ & 30.35 & 30.77 & 28.42 & 89.54 \\
\hline \multirow{9}{*}{$10-15 \mathrm{~cm}$} & Amaranthus retroflexus & 1.17 & 2.56 & 0.27 & 4.00 \\
\hline & Avena sativa & 7.78 & 7.69 & 4.29 & 19.76 \\
\hline & Commelina benghalensis & 5.84 & 2.56 & 14.75 & 23.15 \\
\hline & \begin{tabular}{|l|} 
Digitaria horizontalis \\
\end{tabular} & 1.95 & 2.56 & 0.27 & 4.78 \\
\hline & Leonotis nepetifolia & 6.23 & 7.69 & 2.41 & 16.33 \\
\hline & Portulaca oleracea & 0.39 & 2.56 & 0.27 & 3.22 \\
\hline & Raphanus sativus & 7.00 & 5.13 & 4.02 & 16.15 \\
\hline & $10-15 \mathrm{~cm}(\%)$ & 30.35 & 30.77 & 26.27 & 87.39 \\
\hline & Total $(\%)$ & 100 & 100 & 100 & 300 \\
\hline
\end{tabular}

* Rel. abund. = relative abundance of the given species; Rel. freq. $=$ relative frequency of appearance of the given species; Rel. domin. $=$ relative dominance of the given species; IVI = importance value index of the given species in area. 
becoming important due to its relatively high tolerance to glyphosate.

The no-till, agriculture only area (Table 3), showed the highest number of weed species among the management systems assessed. At the shallower depth, Raphanus sativus (Rab, Rdo, IVI), Commelina benghalensis (Rab, Rdo, IVI) and Leonotis nepetifolia (IVI), followed by Chamaesyce hirta (Rfr), were the most significant weed species (Table 3). At the intermediary depth, Raphanus sativus (Rab, Rfr, Rdo, IVI), Commelina benghalensis (Rdo, IVI) and Amaranthus hybridus (Rfr, IVI) were the most significant weed species. At the deeper depth, plant species were very similar in Rab, Rfr and Rdo, and the following were highlighted according to their IVI, in order of importance: Commelina benghalensis, Raphanus sativus, Amaranthus hybridus (Table 3). In general, 50,27 and $23 \%$ of the total weed infestation at this system germinated from seeds at the

Table 3 - Analysis of weed species and their significance in soil submitted to No-till system (no tillage, agriculture only) for 16 years, sampled at different depths. Embrapa Western Agriculture, Dourados-MS, Brazil, 2011

\begin{tabular}{|c|c|c|c|c|c|}
\hline & No-till (agriculture only) & Rel. abund* & Relat. freq* & Reatl. domin* & IVI* \\
\hline \multirow{11}{*}{$0-5 \mathrm{~cm}$} & Amaranthus hybridus & 2.80 & 4.17 & 0.89 & 7.86 \\
\hline & Amaranthus retroflexus & 5.39 & 6.25 & 1.93 & 13.56 \\
\hline & Brachiaria decumbens & 0.86 & 2.08 & 0.59 & 3.54 \\
\hline & Chamaesyce hirta & 2.16 & 8.33 & 2.67 & 13.16 \\
\hline & Chamaesyce hyssopifolia & 0.86 & 2.08 & 0.59 & 3.54 \\
\hline & Commelina benghalensis & 6.68 & 6.25 & 9.63 & 22.56 \\
\hline & Digitaria horizontalis & 3.23 & 2.08 & 4.89 & 10.2 \\
\hline & Eleusine indica & 1.08 & 2.08 & 0.44 & 3.61 \\
\hline & Euphorbia heterophylla & 2.59 & 2.08 & 2.96 & 7.63 \\
\hline & Leonotis nepetifolia & 4.31 & 6.25 & 4.89 & 15.45 \\
\hline & Raphanus sativus & 17.24 & 6.25 & 25.33 & 48.82 \\
\hline & $0-5 \mathrm{~cm}(\%)$ & 47.2 & 47.92 & 54.81 & 149.93 \\
\hline \multirow{9}{*}{$5-10 \mathrm{~cm}$} & Amaranthus hybridus & 3.23 & 4.17 & 0.3 & 7.7 \\
\hline & Amaranthus retroflexus & 2.16 & 2.08 & 0.3 & 4.53 \\
\hline & Chamaesyce hirta & 0.65 & 2.08 & 0.3 & 3.03 \\
\hline & Chamaesyce hyssopifolia & 1.08 & 4.17 & 0.3 & 5.54 \\
\hline & Commelina benghalensis & 2.16 & 2.08 & 7.85 & 12.09 \\
\hline & Ipomoea grandifolia & 0.65 & 2.08 & 1.04 & 3.77 \\
\hline & Leonotis nepetifolia & 3.02 & 2.08 & 0.59 & 5.69 \\
\hline & Raphanus sativus & 11.42 & 6.25 & 21.93 & 39.6 \\
\hline & $5-10 \mathrm{~cm}(\%)$ & 24.35 & 25 & 32.59 & 81.95 \\
\hline \multirow{11}{*}{$10-15 \mathrm{~cm}$} & Amaranthus hybridus & 5.39 & 4.17 & 0.74 & 10.3 \\
\hline & Amaranthus retroflexus & 0.86 & 2.08 & 0.3 & 3.24 \\
\hline & Chamaesyce hirta & 0.43 & 4.17 & 0.3 & 4.89 \\
\hline & Commelina benghalensis & 7.11 & 4.17 & 4.3 & 15.58 \\
\hline & Digitaria horizontalis & 3.66 & 2.08 & 0.44 & 6.19 \\
\hline & Eleusine indica & 1.29 & 2.08 & 0.74 & 4.12 \\
\hline & Ipomoea grandifolia & 1.94 & 2.08 & 0.3 & 4.32 \\
\hline & Leonotis nepetifolia & 3.45 & 4.17 & 1.33 & 8.95 \\
\hline & Raphanus sativus & 4.31 & 2.08 & 4.15 & 10.54 \\
\hline & $10-15 \mathrm{~cm}(\%)$ & 28.45 & 27.08 & 12.59 & 68.12 \\
\hline & Total $(\%)$ & 100 & 100 & 100 & 300 \\
\hline
\end{tabular}

* Rel. abund. $=$ relative abundance of the given species; Rel. freq. = relative frequency of appearance of the given species; Rel. domin. $=$ relative dominance of the given species; IVI $=$ importance value index of the given species in area 
shallower, intermediary, and deeper depths, respectively.

It is important to note, however, that at the no-till area around $24 \%$ of the overall infestation was by Raphanus sativus, a plant which is introduced for soil coverage whenever grain crops are not being grown at the area. At the shallower depth, around $33 \%$ of the infestation was attributed to this species, whose soil seed bank is often fed when the plant is used as winter cropping. If the appropriate proportion of area covered, number of plants and dry mass accumulated by plants of this species were correctly removed from the raw data at Figures 1, 2 and 3, both areas, conventional and no-till, would tend to be very similar in terms of levels of infestation (data not shown) while keeping the differences in terms of species composition.

Mas et al. (2010) observed that weed communities after five or more years of notill glyphosate-tolerant soyabean cropping systems had: (i) higher relative abundance of perennials (52.1\% versus $31.7 \%$ ), and (ii) higher relative abundance of dicotyledons $(66.3 \%$ versus $38.5 \%)$ than the weed communities of fields with $<5$ years of no-till. At this study, a predominance of broadleaved weeds was also observed at the no-till system.

Under heavy and dense weed infestation, the importance of each species as a competitive component is reduced; thus, there will be a higher equivalence among species at the same area. Surely under such conditions, restrictions imposed by the environment will determine the degree of development of a given plant in detriment of its genetic potential (Pitelly \& Pitelli, 2008). On the other hand, under moderate infestations the type of weed species will determine the difficulty in achieving adequate levels of control (Pereira et al., 2000).

In a study regarding soil characteristics after 12 years of different managements (conventional tillage and no-till), Andrade et al. (2010) highlight the following: (1) the soil physical properties in no-tillage systems remain adequate for plant development; and (2) at the shallower soil layer of the no-till crop succession, soil density values were reduced. This means crop plants usually find a similar or occasionally more suitable environment for their development under no-till systems than under conventional tillage. In addition, the lack of soil disturbance will allow only seeds at relatively shallow depths to emerge, once quiescent seeds keep waiting for proper conditions (light, $\mathrm{O}_{2}$ concentration) to germinate, which may never happen if the soil is kept undisturbed (Morbidoni et al., 2008; Yamashita et al., 2009; Ghaderi-Far et al., 2010). Pereira et al. (2000), comparing conventional and no-till systems in what regards weed infestation, found that the no-till system has always shown a smaller number of weed seedlings per area when compared to the conventional system.

At the crop/livestock integration (Table 4), Brachiaria decumbens (Rab, Rfr, Rdo, IVI) and Commelina benghalensis (IVI) were the most significant weed species; at the intermediary depth, Leonotis nepetifolia (Rab, Rfr, Rdo, IVI), Chamaesyce hyssopifolia (Rdo, IVI) and Richardia brasiliensis (IVI) were the most significant ones (Table 4). At the deeper depth, only Leonotis nepetifolia (Rab, Rfr, Rdo, IVI) was able to cause significant infestation. Generally speaking, 28, 45 and $27 \%$ of the infestation germinated from seeds show respectively at the shallower, intermediary, and deeper sampled depths. Possible explanations for lower infestation at the shallower depth compared to the intermediary one, is that (1) species grown as livestocks are injecting allelopathic compounds into the soil, enhibiting seed germination - aconitic acid as previously mentioned; and (2) animal trampling when livestock is applied has the role of reducing seed feasibility.

The area which was continuously under pasture was the least infested with weeds (Table 5). Only three species were identified at the shallower and intermediary depths, and a single weed species was found at the deepest sampled depth. After 16 years of continuous pasture the number of weed species at the soil seed bank fell to a minimum, probably incapable of causing considerable infestation at the area for some years in case it returned to grain crops.

According to Pandey \& Singh (1991) and Belsky (1992) undisturbed areas tend to have 
Table 4 - Analysis of weed species and their importance in soil submitted to crop/livestock integration for 16 years, sampled at different depths. Embrapa Western Agriculture, Dourados-MS, Brazil, 2011

\begin{tabular}{|c|c|c|c|c|c|}
\hline & Integration crop / pasture & Rel. abund* & Relat. freq* & Relat. domin* & IVI* \\
\hline \multirow{4}{*}{$0-5 \mathrm{~cm}$} & Brachiaria decumbens & 20.83 & 13.04 & 32.64 & 66.52 \\
\hline & Chamaesyce hirta & 0.83 & 4.35 & 0.69 & 5.88 \\
\hline & Commelina benghalensis & 1.67 & 4.35 & 5.56 & 11.57 \\
\hline & $0-5 \mathrm{~cm}(\%)$ & 23.33 & 21.74 & 38.89 & 83.96 \\
\hline \multirow{7}{*}{$5-10 \mathrm{~cm}$} & Amaranthus hybridus & 3.33 & 4.35 & 2.08 & 9.76 \\
\hline & Brachiaria decumbens & 4.17 & 4.35 & 2.78 & 11.29 \\
\hline & Chamaesyce hyssopifolia & 15 & 8.7 & 14.58 & 38.28 \\
\hline & Leonotis nepetifolia & 20.83 & 13.04 & 14.58 & 48.46 \\
\hline & Portulaca oleracea & 0.83 & 4.35 & 1.39 & 6.57 \\
\hline & Richardia brasiliensis & 5.83 & 8.7 & 4.86 & 19.39 \\
\hline & $5-10 \mathrm{~cm}(\%)$ & 50 & 43.48 & 40.28 & 133.76 \\
\hline \multirow{8}{*}{$10-15 \mathrm{~cm}$} & Amaranthus retroflexus & 1.67 & 4.35 & 1.39 & 7.4 \\
\hline & Chamaesyce hirta & 1.67 & 4.35 & 2.78 & 8.79 \\
\hline & Digitaria horizontalis & 4.17 & 4.35 & 0.69 & 9.21 \\
\hline & Galinsoga parviflora & 0.83 & 4.35 & 1.39 & 6.57 \\
\hline & Leonotis nepetifolia & 14.17 & 13.04 & 12.5 & 39.71 \\
\hline & Richardia brasiliensis & 4.17 & 4.35 & 2.08 & 10.6 \\
\hline & $10-15 \mathrm{~cm}(\%)$ & 26.67 & 34.78 & 20.83 & 82.28 \\
\hline & Total $(\%)$ & 100 & 100 & 100 & 300 \\
\hline
\end{tabular}

* Rel. abund. = relative abundance of the given species; Rel. freq. $=$ relative frequency of appearance of the given species; Rel. domin. $=$ relative dominance of the given species; IVI = importance value index of the given species in area

Table 5 - Analysis of weed species and their significance in soil submitted to livestock for 16 years, sampled at different depths. Embrapa Western Agriculture, Dourados-MS, Brazil, 2011

\begin{tabular}{|c|c|c|c|c|c|}
\hline & Pasture only & Relat. abund* & Relat. freq* & Relat. domin* & IVI* \\
\hline \multirow{4}{*}{$0-5 \mathrm{~cm}$} & Brachiaria decumbens & 20.83 & 30.00 & 32.14 & 82.98 \\
\hline & Eleusine indica & 8.33 & 10.00 & 21.43 & 39.76 \\
\hline & Leonotis nepetifolia & 4.17 & 10.00 & 3.57 & 17.74 \\
\hline & $0-5 \mathrm{~cm}(\%)$ & 33.33 & 50.00 & 57.14 & 140.48 \\
\hline \multirow{4}{*}{$5-10 \mathrm{~cm}$} & Brachiaria decumbens & 12.5 & 20.00 & 21.43 & 53.93 \\
\hline & Galinsoga parviflora & 8.33 & 10.00 & 14.29 & 32.62 \\
\hline & Richardia brasiliensis & 4.17 & 10.00 & 3.57 & 17.74 \\
\hline & $5-10 \mathrm{~cm}(\%)$ & 25 & 40.00 & 39.29 & 104.29 \\
\hline \multirow[t]{3}{*}{$10-15 \mathrm{~cm}$} & Digitaria horizontalis & 41.67 & 10.00 & 3.57 & 55.24 \\
\hline & $10-15 \mathrm{~cm}(\%)$ & 41.67 & 10.00 & 3.57 & 55.24 \\
\hline & Total $(\%)$ & 100 & 100 & 100 & 300 \\
\hline
\end{tabular}

* Rel. abund. $=$ relative abundance of the given species; Rel. freq. $=$ relative frequency of appearance of the given species; Rel. domin. $=$ relative dominance of the given species; IVI = importance value index of the given species in area.

lower species richness than corresponding grazed areas, but the authors also state that such change is directly related to the intensity of grazing. In addition, crop/livestock rotation allows grazing to be used as a complimentary (if not the main) off-season method of weed control by the presence of a more continuous and dense canopy which, among other factors, prevent weed seedlings access to light (Severino, 2005). 
The several benefits of crop-livestock integration can be summarized as follows: agronomic benefits, because the productive potential of soil is recovered and maintained; economic benefits, because of product diversification and higher yields, besides quality at a smaller cost; ecological benefits, because the occurrence of crop pest is reduced, and, as a consequence, less pesticide is used; and social benefits, because it results in more consistent income distribution as the livestock and crop activities concentrate income generation at different times (Vilela et al., 2003).

With regards to similarity coefficients among management systems (Table 6, upper section), Felfili \& Venturoli (2000) suggest that similarity indexes above 0.50 indicate high similarity between two compared areas, while Looman \& Campbell (1960) suggested that this coefficient should be interpreted in an empirical manner. At this study, it was assumed that a similarity index higher than 0.40 indicates proper degree of similarity after 16 years of different management. Based on this fact, more aggressive systems like conventional tillage diverge from areas under crop/livestock integration and livestock only, since it is in some degree still connected to the no-till agriculture only system. The no-till system, on the other hand, is in intermediary position once it shows connections with the conventional tillage from one side and crop/ livestock integration and livestock only from the other side. This is more obvious at the shallower depth; these similarities are smoothly reduced as the depth of the soil is increased (Table 6).

When depths are compared within each management system (Table 6, lower section), both the conventional and the no-till systems are very similar with regards to the soil profile in terms of weed composition, while the crop/ livestock integration and the livestock only area show complete divergence among all sampled depths. This means that systems in areas with livestock and grazing, even if not continuous, may affect the feasibility of weed species seeds at soil seed bank, from the surface to deeper depths, and may strongly reduce weed infestation at the area when grain crops are periodically or sporadically grown.

Table 6 - Sørensen's similarity coefficients (QS) in terms of species composition between management systems and between sampled depths, in soils submitted to different managements and uses for 16 years, sampled at different depths. Embrapa Western Agriculture, Dourados-MS, Brazil, 2011

\begin{tabular}{|c|c|c|c|c|}
\hline \multirow{2}{*}{ Management system* } & \multicolumn{4}{|c|}{ Sampled depth $(\mathrm{cm})$} \\
\hline & $0-5$ & \multicolumn{2}{|c|}{$5-10$} & $10-15$ \\
\hline Conv. x no-till & 0.47 & \multicolumn{2}{|c|}{0.46} & 0.63 \\
\hline Conv. $\mathrm{x}$ integration & 0.22 & \multicolumn{2}{|c|}{0.18} & 0.46 \\
\hline Conv. $\mathrm{x}$ pasture & 0.22 & \multicolumn{2}{|c|}{0} & 0.25 \\
\hline No-till $\mathrm{x}$ integration & 0.43 & \multicolumn{2}{|c|}{0.43} & 0.53 \\
\hline No-till x pasture & 0.43 & \multicolumn{2}{|c|}{0} & 0.2 \\
\hline Integration $\mathrm{x}$ pasture & 0.33 & \multicolumn{2}{|c|}{0.44} & 0.29 \\
\hline \multirow{2}{*}{ Sampled depth * } & \multicolumn{4}{|c|}{ Management system } \\
\hline & Conventional & No-till & Crop/livestock & Pasture \\
\hline$(0-5 \mathrm{~cm}) \times(5-10 \mathrm{~cm})$ & 0.73 & 0.74 & 0.22 & 0.33 \\
\hline$(0-5 \mathrm{~cm}) \times(10-15 \mathrm{~cm})$ & 0.77 & 0.8 & 0.22 & 0 \\
\hline$(5-10 \mathrm{~cm}) \times(10-15 \mathrm{~cm})$ & 0.67 & 0.71 & 0.33 & 0 \\
\hline
\end{tabular}

* Sørensen's similarity coefficients (QS) among pairs of data presented, varying from 0 to 1 . Values equal to or higher than 0.40 are considered similar. 
Generally, areas that have livestock, whether continuously or periodically, have fewer amounts of weeds in comparison to systems where only grain crops are grown. In addition, weed composition is different among management systems. Livestock affected seed germination potential, as seedlings of weed species under such managements took longer to germinate and emerge from the soil surface. And finally, agriculture only systems, regardless of the chosen tillage, presented high similarity in terms of weed composition along the soil profile, while systems with livestock diverge among sampled depths. Screening of the soil seed bank showed to be a very efficient method of understanding the dynamics of occurrence and severity of weed species in a given management system. Conservationist models of land exploration contribute to reduce the severity of weed species occurrence in these areas.

\section{ACKNOWLEDGEMENTS}

The authors would like to thank the financial support from FINEP-FNDCT, MCT, which allowed the conduction of this research.

\section{LITERATURE CITED}

AMARAL, J. A. M. et al. Levantamento semidetalhado dos solos do campo experimental de Dourados, da Embrapa Agropecuária Oeste, Município de Dourados, MS. Dourados: Embrapa Agropecuária Oeste; Rio de Janeiro: Embrapa Solos, 2000. 68 p. (Embrapa Agropecuária Oeste. Documentos, 22; Embrapa Solos. Documentos, 15)

ANDRADE, A. P. et al. Physical properties of a humic cambisol under tillage and cropping systems after 12 years. R. Bras. Ci. Solo, v. 34, n. 1, p. 219-226, 2010

BELSKY, A. J. Effects of grazing, competition, disturbance and fire on species composition and diversity in grassland communities. J. Veget. Sci., v 3, n. 1, p. 187-200, 1992.

BULHER, D. D. et al. The effect of maize residues and tillage on emergence of Setaria faberi, Abutilon theophrasti, Amaranthus retroflexus e Chenopodium album. Weed Res., v. 36, n. 2, p. 153-165, 1996

DEUBER, R. Ciência das plantas daninhas: fundamentos. Jaboticabal: Funep, 1992. v. 1. 431 p.

FELFILI, J. M.; VENTUROLI, F. Tópicos em análise de vegetação. Brasília, DF: Universidade de Brasília, Faculdade de Tecnologia, 2000. 34 p. (Comunicações Técnicas Florestais, v. 2, n. 2).
FIETZ, C. R.; FISCH, G. F. O clima da região de Dourados, MS. Dourados: Embrapa Agropecuária Oeste, 2006. 32 p. (Embrapa Agropecuária Oeste. Documentos, 85).

FRIEBE, A. et al. Phytotoxins from shoot extracts and root exsudates of Agropyron repens seedlings. Phytochemistry, v. 38, n. 5, p. 1157-1159, 1995.

GHADERI-FAR, F. et al. Influence of environmental factors on seed germination and seedling emergence of yellow sweet clover (Melilotus officinalis). Planta Daninha, v. 28, n. 3, p. $463-469,2010$.

LOOMAN, J.; CAMPBELL, J. B. Adaptation of Sørensen's $\mathrm{K}$ (1948) for estimating unit affinities in prairie vegetation Ecology, v. 41, n. 3, p. 409-416, 1960.

MARCHEZAN, E. et al. Dinâmica do banco de sementes de arroz vermelho afetado pelo pisoteio bovino e tempo de pousio da área. Planta Daninha, v. 21, n. 1, p. 55-62, 2003

MAS, M. T. et al. Weed communities of transgenic glyphosate-tolerant soyabean crops in ex-pasture land in the southern Mesopotamic Pampas of Argentina. Weed Res., v. 50, n. 4 , p. $320-330,2010$

MORBIDONI, M. et al. Effects of environmental factors on seed germination of Anthyllis barba-jovis L. Plant Biosyst., v. 142 , n. 2 , p. $275-286,2008$.

MUELLER-DOMBOIS, D.; ELLENBERG, H. Aims and methods of vegetation ecology. New York: Wiley, 1974. $547 \mathrm{p}$.

NORSWORTHY, J. K. et al. Differences in weed tolerance to glyphosate involve different mechanisms. Weed Technol., v. 15 , n. 4 , p. $725-731,2001$

PANDEY, C. B.; SINGH, J. S. Influence of grazing and soil conditions on secondary savanna vegetation in India. J. Veget. Sci., v. 2, n. 1, p. 95-102, 1991.

PEREIRA, E. S. et al. Avaliações qualitativas e quantitativas de plantas daninhas na cultura da soja submetida aos sistemas de plantio direto e convencional. Planta Daninha, v. 18, n. 2, p. $207-216,2000$.

PITELLI, R. A.; PITELLI, R. L. C. M. Biologia e ecofisiologia das plantas daninhas. In: VARGAS, L.; ROMAN, E. S. (Eds.). Manual de manejo e controle de plantas daninhas. Passo Fundo: Embrapa Trigo, 2008. p. 11-38.

POPAY, I.; FIELD, R. Grazing animals as weed control agents. Weed Technol., v. 10, n. 1, p. 217-231, 1996.

PUTNAN, A. R.; DeFRANK, J. Use of phytotoxic plant residues for selective weed control. Crop Protec., v. 2, n. 2, p. 173-181, 1983.

Planta Daninha, Viçosa-MG, v. 29, n. 4, p. 725-736, 2011 
SEVERINO, F. J. Supressão da infestação da plantas daninhas pelo sistema de produção de integração lavoura-pecuária. 2005. 113 f. Tese (Doutorado em Fitotecnia) - Escola Superior de Agricultura "Luiz de Queiroz", Universidade de São Paulo, Piracicaba, 2005.

SØRENSEN, T. A method of establishing groups of equal amplitude in plant sociology based on similarity of species and its application to analyses of the vegetation on Danish commons. Biologiske Skrifter, v. 5, n. 4, p. 1-34, 1957.

VILELA, L. et al. Benefícios da integração lavoura pecuária. In: KLUTHCOUSKI, J. et al. (Ed.). Integração lavourapecuária. Santo Antônio de Goiás: Embrapa Arroz e Feijão, 2003. p. $145-170$.
VOLL, E. et al. Ácido aconítico em sementes de espécies de plantas daninhas de diferentes locais. Planta Daninha, v. 28, n. 1, p. $13-22,2010$

VOLL, E. et al. Chemical interactions of Brachiaria plantaginea with Commelina benghalensis and

Acanthospermum hispidum in soybean cropping systems. J. Chem. Ecol., v. 30, n. 7, p. 1467-1475, 2004.

VOLL, E. et al. A dinâmina das plantas daninhas e práticas de manejo. Londrina: Embrapa Soja, 2005. 85 p (Embrapa Soja. Documentos, 260).

YAMASHITA, O. M. et al. Fatores ambientais sobre a germinação de Emilia sonchifolia. Planta Daninha, v. 27, n. 4, p. 673-681, 2009. 